\title{
IDENTIFIKASI ANGGREK ALAM PADA KAWASAN RAWAN GANGGUAN DI SUAKA MARGA SATWA BUKIT RIMBANG DAN BUKIT BALING RESORT KUANTAN SINGINGI
}

\author{
Pebra Heriansyah", Seprido, Desta Andriani \\ Universitas Islam Kuantan Singingi Teluk Kuantan, Jl. Gatot Subroto KM 7, Kebun Nenas, Teluk Kuantan, Sungai \\ Jering, Kuantan Singingi, Kabupaten Kuantan Singingi, Riau 29566 \\ `Email korespondensi: hpebra92@gmail.com
}

\begin{abstract}
Natural orchids are a wealth owned by a Region, so its existence needs to be identified in order to avoid extinction. The purpose of this study is to identify natural orchids in the Disturbance Prone Area in Bukit Rimbang Wildlife Sanctuary and Bukit Baling Resort Kuantan Singingi. The data collection method in this study uses purposive sampling method through the identification stage either by means of photo or image capture and the resulting specimen will be identified with the help of an identification book. The conclusion of this study was found 12 types of orchids and 10 genera in the Area Prone to Disturbance of Wildlife Sanctuary Bukit Rimbang and Bukit Baling, from an altitude of 90 - 200 meters above sea level. Of these 12 species there are several endangered species namely Grammatophyllum speciosum Blume found only at one point, Dendrobium aloifolium (Blume) Reichb.f, Robiquetia spathulata (Blume) J.J.Smith, Epigeneium sp, Cimbidium spp, found at 2 plants.
\end{abstract}

Keywords: disturbance prone, identification, natural orchids

\begin{abstract}
Abstrak. Anggrek alam merupakan salah satu kekayaan yang dimiliki oleh suatu kawasan, sehingga keberadaannya perlu diidentifikasi agar tidak terjadi kepunahan. Tujuan penelitian ini adalah untuk mengidentifikasi anggrek alam di kawasan rawan gangguan di Suaka marga satwa bukit rimbang dan bukit baling resort Kuantan Singingi Provinsi Riau. Metode pengumpulan data dalam penelitian ini menggunakan metode purposive sampling melalui tahapan identifikasi baik dengan cara pengambilan hasil foto atau gambar dan spesimen hasilnya akan diidentifikasi dengan bantuan buku identifikasi. Hasil penitian ini, ditemukan 12 jenis anggrek dan 10 genera di Kawasan Rawan Gangguan Suaka Marga Satwa Bukit Rimbang dan Bukit Baling, dari ketinggian 90 - 200 mdpl. Dari 12 jenis ini ada beberapa jenis yang terancam punah yaitu Grammatophyllum speciosum Blume hanya ditemukan di satu titik saja, Dendrobium aloifolium (Blume) Reichb.f, Robiquetia spathulata (Blume) J.J.Smith, Epigeneium sp, Cimbidium spp, ditemukan di 2 titik.
\end{abstract}

Kata kunci: anggrek alam, identifikasi, rawan gangguan

\section{PENDAHULUAN}

Anggrek merupakan tanaman yang terkenal dengan keindahan dan bentuk bunga yang sangat khas, tanaman yang tersebar luas diberbagai belahan dunia ini memiliki sejuta pesona yang menarik bagi penganggrek, maupun penikmat keindahan tanaman tersebut, selain keindahan morfologi tanaman anggrek ini, juga memiliki aroma yang begitu khas, sehingga menimbulkan relaksasi bagi penikmatnya (Heriansyah, 2019).

Anggrek alam merupakan anggrek yang secara endemik berada di habitat aslinya (Heriansyah, Trinop, \& Rover, 2014), namun keberadaan anggrek alam ini sangat bergantung kepada kelestarian hutan tempatnya berada, penebangan hutan secara illegal dan penjarahan anggrek di alam menjadikan anggrek ini kian terancam keberadaannya, salah satu kawasan yang menjadi habitat alam anggrek adalah kawasan Suaka Marga Satwa (SM) Bukit Rimbang Baling, Kabupaten Kuantan Singingi,

\section{Provinsi Riau.}

Kawasan konservasi Rimbang Baling memiliki nama resmi Suaka Margasatwa Bukit Rimbang dan Bukit Baling, luasnya kurang lebih 136.000 Ha. Mula-mula kawasan tersebut ditetapkan berdasarkan Keputusan . Gubernur No. 149N11982, tanggal 21 Juni 1982 (KeneJie dan Zanir, 2002) kemudian pada tanggal 6/Juni/1986 dikukuhkan menjadi Suaka Margasatwa Bukit Rimbang-Baling berdasarkan SK (Surat Keputusan) Menteri Kehutanan No. 1731Kpts-III1986 (Ditjenphka, 2017) Secara administratif kawasannya terletak di Kabupaten Kampar dan Kabupaten Kuantan Singingi (Kuansing), Riau (Puspitaningtyas, 2009).

Puspitaningtyas, (2009) menjelaskan bahwa eksplorasi yang dilakukan pada tahun 2009 mencatat bahwa di Kawasan Suaka Marga Satwa Bukit Rimbang dan Bukit Baling, ditemukan anggrek yang dikoleksi terdiri atas 21 marga dan 49 jenis.

Habitat anggrek di Kawasan Suaka Marga 
Satwa Bukit Rimbang dan Bukit Baling mengalami degradasi seiring dengan berjalannya waktu. Moersidik dan Suandi (2014) melaporkan bahwa dalam kurun waktu empat tahun terjadi degradasi area penyangga di kawasan SM Bukit Rimbang dan Bukit Baling mencapai 82,25 \%. terutama daerah yang rawan gangguan. Daerah rawan gangguan merupakan daerah yang berbatasan langsung dengan perkebunan penduduk, dengan radius 10 hektar dari pinggir kawasan.

Sejak kajian terakhir yang dilakukan oleh Moersidik dan Suandi (2014) hingga saat ini belum tersedia lagi data sebaran anggrek alam di kawasan rawan gangguan SM Bukit Rimban, Sehingga sangat perlu dilakukan eksplorasi di kawasan rawan gangguan ini, untuk mengantisipasi dan meminimalisir serta dijadikan sebagai dasar dalam melakukan konservasi nantinya.

\section{METODE}

Penelitian ini dilaksanakan di Kawasan Rawan Gangguan pada Suaka Marga Satwa Bukit Rimbang dan Bukit Baling Resort Kuantan Singingi, Kabupaten Kuantan Singingi, Provinsi Riau, pada bulan Mei 2019.
Pengamatan dilakukan pada semua jenis anggrek alam yang ditemukan pada Kawasan Rawan Gangguan pada Suaka Marga Satwa.

Bukit Rimbang dan Bukit Baling. Teknik pengumpulan data dalam penelitian ini menggunakan metode purposive sampling melalui tahapan identifikasi baik dengan cara pengambilan hasil foto atau gambar dan spesimen hasilnya akan diidentifikasi dengan bantuan buku identifikasi (Comber, 2001).

\section{Identifikasi anggrek}

Identifikasi anggrek langsung dilakukan di lapangan sampai tingkat spesies jika tidak ditemukan maka akan sampai tingkat genus. Untuk mendapatkan hasil sampai tingkat jenis dilakukan dengan mengidentifikasi anggrek baik dari bentuk daun, batang (bulb), serta warna dan bentuk bunga. Identifikasi ditulis dengan menggunakan thally sheet, yang memuat data- data anggrek yang ditemukan pada lokasi pengamatan. Pengambilan data untuk identifikasi dilakukan dengan cara membuat foto dan pengambilan spesimen. Selain itu dilakukan pengambilan data dengan mencatat ciri-ciri morfologi dari jenis tumbuhan anggrek yang ditemukan.

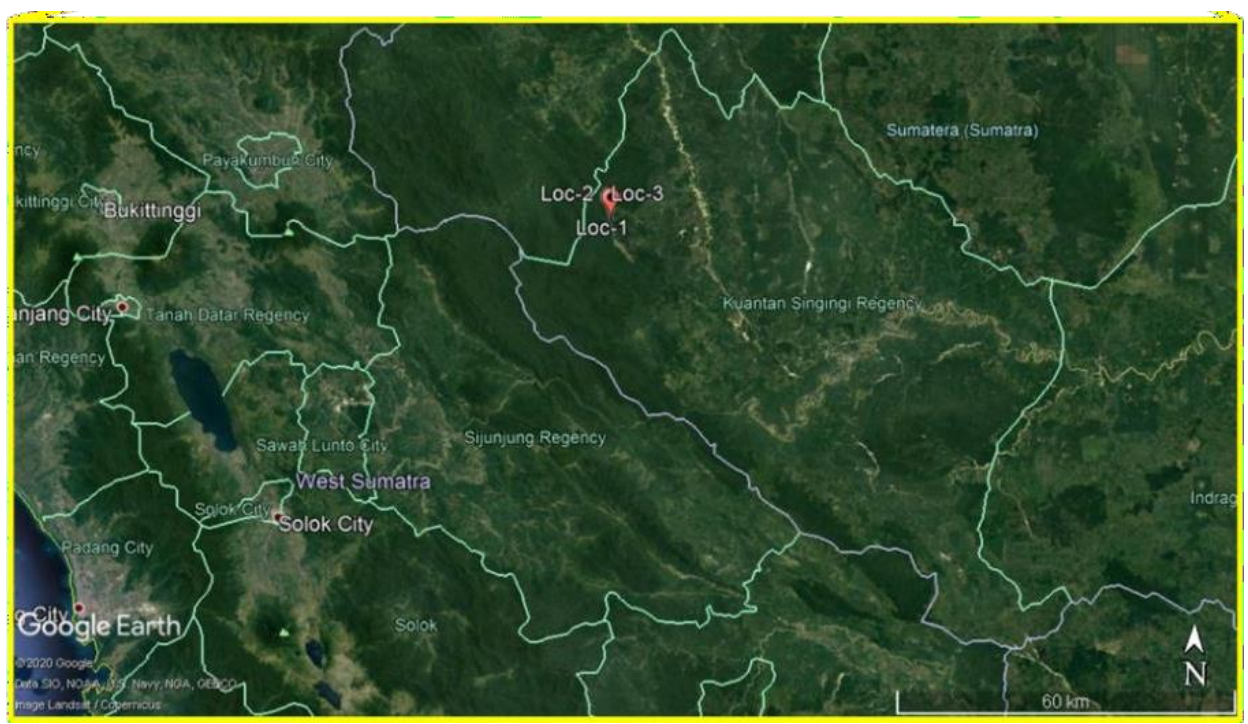

Gambar 1. Peta lokasi penelitian di Kawasan Suaka Marga Satwa Bukit Rimbang dan Bukit Baling, Resort Kabupaten Kuantan Singingi, Provinsi Riau

\section{HASIL DAN PEMBAHASAN}

1. Anggrek Alam Kawasan Suaka Marga Satwa Rimbang Baling, Resort Kuantan Singingi, Provinsi Riau
Penelitian ini dilakukan dengan menjelajah titik-titik yang sesuai dengan habitat anggrek. Berikut adalah tabel hasil identifikasi tanaman anggrek alam di Kawasan Suaka Marga Satwa Rimbang Baling. 
Tabel 1. Hasil identifikasi anggrek di Kawasan Rawan Gangguan Suaka Marga Satwa Bukit Rimbang dan Bukit Baling Resort Kuantan Singingi, Provinsi Riau

\begin{tabular}{clccc}
\hline NO & \multicolumn{1}{c}{ Nama Jenis } & Jumlah & Ketinggian & Habitat \\
\hline 1 & Dendrobium crumenatum & 4 & $124 \mathrm{mdpl}$ & Epifit \\
2 & Claderia viridiflora Hook.f & 100 & $126 \mathrm{mdpl}$ & Teresterial \\
3 & Grammatophyllum speciosum Blume & 1 & $135 \mathrm{mdpl}$ & Epifit \\
4 & Coelogyne rochussenii De Vriese & 3 & $92 \mathrm{mdpl}$ & Epifit \\
5 & Bulbophyllum vaginatum & 5 & $140 \mathrm{mdpl}$ & Epifit \\
6 & Dendrobium aloifolium (Blume) Reichb.f. & 2 & $145 \mathrm{mdpl}$ & Epifit \\
7 & Bromheadia alticola Ridl. & 4 & $157 \mathrm{mdpl}$ & Epifit \\
8 & Bromheadia finlaysoniana (Lindl.) Miq. & 20 & $160 \mathrm{mdpl}$ & Teresterial \\
9 & Robiquetia spathulata (Blume) J.J.Smith & 2 & $190 \mathrm{mdpl}$ & Epifit \\
10 & Epigeneium sp. & 2 & $192 \mathrm{mdpl}$ & Epifit \\
11 & Eria bractescens Lindl. & 5 & $192 \mathrm{mdpl}$ & Epifit \\
12 & Cimbidium sp. & 2 & $200 \mathrm{mdpl}$ & Epifit \\
\hline
\end{tabular}

\section{Anggrek Grammatophyllum speciosum Blume}

Anggrek Grammatophyllum speciosum Blume merupakan anggrek yang sudah terancam dikawasan rawan gangguan ini. Berdasarkan pengamatan di lapangan, terlihat habitat anggrek ini banyak diserobot oleh penjarah untuk mengambil kayu inangnya. Titik tumbuh anggrek ini hanya ditemukan di satu titik saja.

Habitat dari anggrek ini, dapat kita temukan pada ketinggian $135 \mathrm{mdpl}$, tergolong anggrek epifit, umumnya tumbuh bergerombol pada cabang inang. Bukan hanya di Kawasan Suaka Marga Satwa Bukit Rimbang dan Bukit Baling, anggrek Grammatophyllum speciosum Blume juga telah dinyatakan langka secara nasional. Pengalihan fungsi habitat aslinya seperti pembukaan lahan. Berdasarkan Peraturan Pemerintah Republik Indonesia No. 7 tahun 1999 tanggal 27 Januari tahun 1999, anggrek tebu (Grammatophyllum speciosum Blume) termasuk tanaman yang dilindungi (Nuriah et. al., 2018).

Anggrek tebu (Grammatophyllum speciosum Blume), merupakan anggrek berukuran besar. Tumbuh berumpun, tegak keatas pada setiap batang. Akar anggrek ini berbentuk akar serabut berwarna putih kecoklatan, tipe pertumbuhan batang berwarna hijau dengan bercak kehitaman. Panjang batang berkisar antara 50-70 cm. daun anggrek berbentuk pita talang dengan panjang berkisar antara 39-60 cm. Lebar daun rata-rata $3 \mathrm{~cm}$ dengan bentuk meruncing dan memiliki tulang daun (Bieth dan Arobaya, 2020).

\section{Anggrek Dendrobium aloifolium (Blume) Reichb.f. \\ Anggrek Dendrobium aloifolium} (Blume) Reichb.f. merupakan golongan anggrek epifit yang ditemukan pada ketinggian 145 mdpl, keberadaannya di Kawasan Rawan Gangguan SM Bukit Rimbang dan Bukit Baling semakin mengalami degradasi. Hanya ditemukan 2 titik tumbuh di kawasan ini.

Morpologi anggrek Dendrobium aloifolium (Blume) Reichb.f memiliki ciri yang sangat khas dengan bunga berwarna putih, terlihat begitu mungil tepat di ujung batang, daunnya juga menarik jika diperhatikan karena mirip dengan kepang rambut (Puspitaningtyas, 2002).

\section{Anggrek Robiquetia spathulata (Blume)}

\section{J.J.Smith}

Anggrek Robiquetia spathulata

(Blume) J.J.Smith merupakan golongan anggrek epifit yang ditemukan pada ketinggian 190 mdpl, keberadaannya di kawasan ini hanya terdapat pada 2 titik saja. Penurunan populasi tanaman ini dikarenakan berbagai faktor diantaranya adalah adanya aktivitas yang manusia di sekitar habitatnya.

Ciri morfologi Anggrek Robiquetia spathulata (Blume) J.J.Smith ini, batangnya memiliki pendulous panjangnya $30-50 \mathrm{~cm}$, 
daun anggrek nya berukuran $8-10$ x 2,5-5 cm. bunganya berwarna kuning, berbintik- bintik dan bersatu dengan ungu kecoklatan. Biasanya berbunga pada bulan mei-juli (Gogoi et. al.,2010).

\section{Anggrek Epigeneium sp.}

Anggrek Epigeneium sp. Adalah anggrek yang tergolong epifit, ditemukan pada ketinggian 192 mdpl, keberadaannya di kawasan hanya ditemui pada 2 titik, hal ini disebabkan karena adanya gangguan aktivitas manusia di sekitar habitat. Bukti gangguan terlihat dengan adanya kerusakan dibawah pokok inangnya.

Morfologi tanaman anggrek Epigeneium sp., dicirikan dengan bentuk bunga yang khas, posisi sepal lateral dan kelopak pada kolom-kaki yang membentuk mentum. Pada Epigeneium, pucuk udara berakhir dalam pseudobulb satu, dua, atau tiga, bulat telur atau kerucut yang hanya terdiri dari satu ruas, tunas baru yang muncul di dasar pseudobulb. Tunas ini adalah paling sering merayap dan tegak atau, kadang, terjumbai, dan ditutupi dengan selubung coklat imbricate yang mencolok saat muda. Itu susunan bunganya ramping, dengan satu sampai sekitar dua puluh bunga di setiap tangkai, dan muncul di antara atau tepat di bawah daun. Bunga menarik dan relatif berumur panjang (Wood, 2004).

\section{Anggrek Cimbidium sp.}

Anggrek Cimbidium sp termasuk golongan anggrek epifit yang hanya dijumpai pada 2 titik saja, pada kawasan yang terganggu. Anggrek ini ditemukan pada ketinggian $200 \mathrm{mdpl}$, tepat berada di sekitar lokasi bekas perambahan, sehingga inang tanaman hanya di temukan satu pokok saja di sekitar lokasi.

Anggrek Cymbidium sp, memiliki ciri khas, bunga anggrek ini berukuran 2-3 inci, dengan 3 sepal berwarna, 2 kelopak berwarna dan kelopak ketiga yang dimodifikasi menjadi bibir yang diikat atau dibatasi dan diwarnai berbeda. Batangnya memiliki panjang 16-24 inci dengan 8-20 bunga. Tanaman ini digolongkan sebagai monokotil, daun sebagian besar berurat paralel. Kebanyakan kultivar tidak memiliki wewangian (Widowati, 2015).

\section{Anggrek Dendrobium crumenatum}

Anggrek Dendrobium crumenatum termasuk golongan anggrek epifit yang ditemukan pada ketinggian $124 \mathrm{mdpl}$, anggrek ini ditemukan pada 4 titik, hal ini mengindikasikan bahwa populasi nya masih tetap terancam, meskipun ditemukan di 4 titik, karena di setiap titik selalu ditemukan bekas aktivitas manusia seperti pengambilan anak kayu, dan perusakan tanaman inang.

Morfologi tanaman anggrek Dendrobium crumenatum memiliki ciri sebagai berikut, bunga berbentuk bulat, bundar seperti kupu- kupu, dengan beragam warna. Buah tanaman anggrek ini berwarna hijau, berukuran besar dan membesar pada bagian tengah buahnya, berbentuk seperti kapsul yang terbelah menjadi enam bagian (Heriansyah et al.,2020) Daun dari tanaman ini terlihat berbentuk lanset ramping dan membulat, setiap daun tumbuh berhadapan atau berpasangan. Batangnya tergolong simpodial, beruas-ruas. Anakan biasanya tumbuh diantara ruas batang, maupun rimpang (Hidayati et. al.,2016)

\section{Anggrek Coelogyne rochussenii De Vriese}

Anggrek Coelogyne rochussenii De Vriese termasuk golongan anggrek epifit, ditemukan pada ketinggian 92 mdpl. Anggrek ini ditemukan pada 3 titik, dengan kondisi habitat terganggu. Vegetasi di sekitar tanaman inang sudah tidak alami lagi, hal ini menunjukkan bahwa ada gangguan pada hanitatnya.

Morpologi Anggrek C. rochussenii merupakan anggrek epifit dengan tipe simpodial. Rimpang menyebar dan bercabang keluar. Bulb anggrek $\mathrm{C}$. rochussenii berbentuk oval, daun muncul dari ujung bulb dan masing-masing bulb mendukung dua daun. Daun anggrek C. rochussenii berbentuk bujur telur dengan ujung runcing. perbungaan pendulous pada anggrek Crochussenii muncul dari dasar batang dan menjuntai 20-35 bunga yang mekar secara bersama-sama dengan warna hijau kekuningan (Hartini dan Wawangningrum, 2009).

\section{Anggrek Bromheadia sp.}

Anggrek Bromheadia spesies yang ditemukan di kawasan ada dua jenis, yaitu Bromheadia alticola Ridl. dan Bromheadia 
finlaysoniana (Lindl.) Anggrek $B$. alticola Ridl merupakan golongan anggrek epifit, ditemukan pada ketinggian 157 mdpl, pada 4 titik inang berbeda. Sementara $B$. finlaysoniana (Lindl.) merupakan golongan anggrek teresterrial yang dijumpai pada ketinggian 160 mdpl, pada 20 titik berbeda. Habitat anggrek ini di temukan pada lahan yang sudah dirambah dengan vegetasi pakis.

Morfologi akar tanaman anggrek terestrial (jenis anggrek tanah berbentuk silindris, berdaging, lunak dan mudah patah. Bagian ujung akar meruncing, licin dan sedikit lengket. Dalam keadaan kering akar akan tampak berwarna putih keperak-perakkan dan hanya bagian ujung akar saja yang berwarna hijau atau tampak agak keunguan. Akar yang sudah tua akan berwarna coklat tua dan kering. Akar anggrek berfilamen, yaitu lapisan luar yang terdiri dari beberapa lapis sel berongga dan transparan, serta merupakan lapisan pelindung pada sistem saluran akar. Batang tanaman anggrek Bromheadia Finlaysoniana (Lind.) Miq merupakan golongan monopodial, artinya hanya mempunyai batang utama, bentuk batangnya ramping, tidak berumbi tangkai bunga keluar dijung batang, dan daun tersusun disepanjang batang tanaman. Bromheadia Finlaysoniana (Lind.) Miq ini daunnya tergolong berbentuk talang, artinya helaian daun yang kiri dan kanan membentuk sudut, sehingga bentuk daunnya menyerupai talang. Bunga tanaman anggrek memiliki beberapa bagian utama yaitu sepal (daun kelopak), petal (daun mahkota) stamen (benang sari), pistil (putik), dan ovarium (bakal buah). Sepal anggrek berjumlah tiga buah, sepal bagian atas disebut sepal dorsal, sedangkan 2 lainnya disebut sepal lateral.

Anggrek memiliki tiga buah petal, petal yang pertama dan keduanya letaknya berseling dengan sepal, petal ketiga mengalami modifikasi menjadi labellum (bibir), pada labellum terdapat gumpalan- gumpalan yang mengandung protein, minyak dan zat pewangi, pada bunga anggrek juga terdapat colum (tugu) yang terdapat pada bagian tengah bunga merupakan tempat alat reproduksi jantan dan alat reproduksi betina (Andiani, 2016).

\section{Anggrek Bulbophyllum vaginatum}

Anggrek Bulbophyllum vaginatum Merupakan kelompok anggrek epifit yang ditemui pada ketinggian $140 \mathrm{mdpl}$, ditemui pada 5 titik berbeda, anggrek ini mengalami ancaman karena banyak tumbuh pada inang yang mati, sehingga tanaman banyak yang ikut jatuh bersama inangnya. Pada saat eksplorasi dilapangan banyak ditemukan pada kayu yang telah melapuk ditanah.

Morfologi anggrek Bulbophyllum vaginatum. Dicirikan dengan bunga yang berwarna putih, dengan sepal yang menjuntai disekeliling bunga membentuk setengah lingkaran. Rimpang pada anggrek ini merupakan tempat tumbuh pseudobulb yang menopang dua daun yang tebal dan kaku berwarna hijau gelap (Wulanesa, Soegianto, and Basuki, 2017).

\section{Anggrek Eria bractescens Lindl.}

Anggrek Eria bractescens Lindl. merupakan golongan anggrek epifit ditemukan pada ketinggian $192 \mathrm{mdpl}$. Ditemukan pada 5 titik. Keadaan habitat terganggu dengan adanya kerusakan vegetasi di sekitar inang. Morfologi anggrek ini dicirikan dengan bunga berwarna putih bersusun 10 -

15 bunga, bunga tumbuh di ujung batang diantara dua daunnya. Bulb pada anggrek ini memanjang dan menumpuk pada rimpang yang berdekatan (Bajracharya, 2001).

\section{Anggrek Claderia viridiflora Hook.f}

Anggrek Claderia viridiflora Hook.f merupakan anggrek tanah (terrestrial) yang paling banyak dijumpai pada ketinggian 126 mdpl. Anggrek ini ditemukan sebanyak 100 titik hidup diantara anggota vegetasi lain yang berdaun lunak. Habitat nya terganggu namun ketahanan dan daya adaptasi pada spesies ini cukup bagus.

Morfologi anggrek ini ditandai dengan bunga kuning bercampur hijau pucat. Dengan panjang batang 1-3 cm, tidak memiliki umbi semu. Daun memeluk batang 8-24 cm, dan lebar daun 1,3 - 4,5 cm, hidup diantara tanaman yang tinggi dan ternaungi (Des, et. al., 2015). 

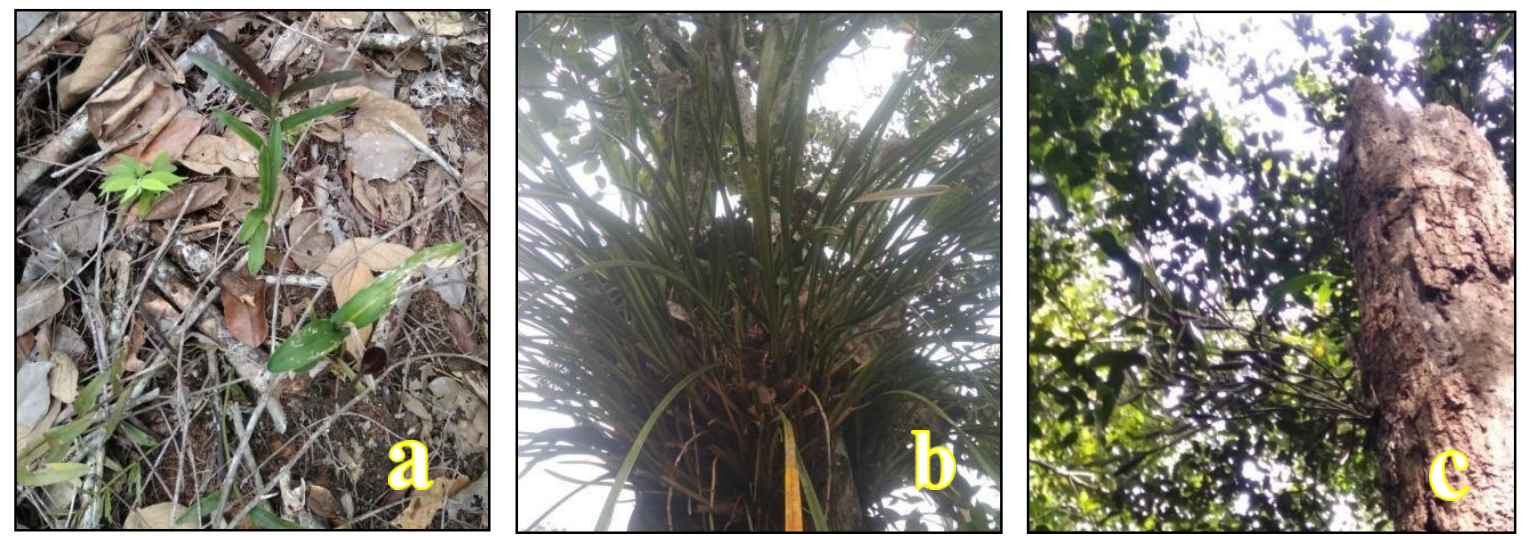

Gambar 1. Habitat Anggrek di Kawasan Rawan Gangguan SM. Bukit Rimbang dan Bukit

Baling a. habitat anggrek teresterial $\mathrm{b}$ dan $\mathrm{c}$. Habitat anggrek epifit

\section{SIMPULAN}

Kesimpulan penelitian ini adalah ditemukan 12 jenis anggrek dan 10 genera di Kawasan Rawan Gangguan Suaka Marga Satwa Bukit Rimbang dan Bukit Baling, dari ketinggian 90 - 200 mdpl. Dari 12 jenis ini ada beberapa jenis yang terancam punah yaitu Grammatophyllum speciosum Blume hanya ditemukan di satu titik saja, Dendrobium aloifolium (Blume) Reichb.f, Robiquetia spathulata (Blume) J.J.Smith, Epigeneium sp, Cimbidium spp, ditemukan di 2 titik.

Penelitian selanjutnya direkomendasikan untuk melakukan identifikasi lanjutan untuk kawasan yang lebih luas pada kawasan.

\section{UCAPAN TERIMA KASIH}

Ucapan terimakasih kepada Universitas Islam Kuantan Singingi, melalui lembaga Penelitian dan Pengabdian Kepada Masyarakat (LPPM) yang telah mendanai penelitian skema hibah universitas pada tahun

\section{DAFTAR PUSTAKA}

Andiani, Y. (2016). Usaha Pembibitan Anggrek dalam Botol (Teknik In-vitro). Yogyakarta: Pustaka Baru Press.

Bajracharya, D.M., 2001. Distribution of Genus Eria Lindley (Orchidaceae) in the Himalayan Region. Nepal Journal of Science and Technology, 3(1). Eksplorasi Dan Indentifikasi JenisJenis Anggrek Di Kawasan Hutan Pulau Mansinam Kabupaten
Manokwari. Jurnal Kehutanan Papuasia, 6(1), pp.106-112.

Des, M., Nursyahra, N. and Liza, S., 2015. Jenis-Jenis Anggrek Alam Yang Ditemukan Di Desa Bosua Kecamatan Sipora Selatan Kabupaten Kepulaun Mentawai. Eksakta, 2, p.83.

DitjenpLHK,2017http://www.ditjenphka.go. id lkawasan filelsm. \%20bukit>> 1020rimbang\%20- \& \%20baling. doc07. doc\%20ok.pdf., n.d diakses 1 September 2020

Gogoi, K., Borah, R.L. and Sharma, G.C., 2010. Orchid flora of Dibru-Saikhowa National Park and Biosphere Reserve, Assam, India.

Heriansyah, P., Jumin, H.B. and Maizar, M., 2020. In-Vitro Rooting Induction On The Embryo Somatic Of Dendrobium Species From Riau Province Indonesia. Paspalum: Jurnal Ilmiah Pertanian, 8(2), pp.93-98. http://dx.doi.org/10.35138/paspalum.v $8 \mathrm{i} 2.190$

Heriansyah, P., Sagiarti, T. And Rover, R., 2014. Pengaruh Pemberian Myoinositol Dan Arang Aktif Pada Media Sub Kultur Jaringan Tanaman Anggrek (Dendrobium SP). Jurnal Agroteknologi, 5(1), pp.9-16. http://dx.doi.org/10.24014/ja.v5i1.114 $\underline{2}$

Heriansyah, P., 2019. Multiplikasi Embrio Somatis Tanaman Anggrek (Dendrobium sp) Dengan Pemberian Kinetin Dan Sukrosa Secara In-Vitro. 
Jurnal Ilmiah Pertanian, 15(2). https://doi.org/10.31849/jip.v15i2.197 $\underline{4}$

Hidayati, N.Z., Saptadi, D. and Soetopo, L., 2016. Analisis hubungan kekerabatan

20 spesies anggrek Dendrobium berdasarkan karakter morfologi. Jurnal Produksi Tanaman, 4(4), pp.291-297.

Wood, J., 2004. 50 Epigeneium Cacuminis: Orchidaceae. Curtis's Botanical Magazine, 21(3), pp.197- 204.

KeneJie, J., M. Zanir. (2002). Buku Informasi Kawasan Konservasi di Propinsi Riau. Departemen Kehutanan, Direktorat Jenderal Perlindungan Hutan dan Konservasi Alam, Pekanbaru, Riau: Balai Konservasi Sumber Daya Alam Riau.

Nuriah, E.N., Marveldani, M. and Shintarika, F., 2018. Pengaruh Aplikasi Paclobutrazol dan KNO3 Terhadap Pertumbuhan dan Pembungaan Anggrek Tebu (Grammatophyllumspeciosum blume). In Prosiding Seminar Nasional
Pengembangan Teknologi Pertanian.

Puspitaningtyas D.M. (2009). Eksplorasi Tumbuhan Di Kawasan Suaka Margasatwa Bukit Rimbang Baling RIAU. Prosiding Seminar Nasional Biologi XX dan Kongres PBI XIV UIN Malik; Malang 1986(1731):167173.

Puspitaningtyas, D.M., 2002. Eksplorasi dan inventarisasi anggrek di Kawasan Kebun Raya Bukit Sari, Jambi. BioSMART, 4(2), pp.55-59.

Wulanesa, W.O.S., Soegianto, A. and Basuki, N., 2017. Eksplorasi dan karakterisasi anggrek epifit di hutan coban trisula kawasan taman nasional bromo tengger semeru. Jurnal Produksi Tanaman, 5(1).

Widowati, D.A.H., 2015. Inventarisasi Keanekaragaman Anggrek (Orchidaceae) di Hutan Resort Way Kanan Balai Aman Nasional Way Kambas Sebagai Sumber Informasi dalam Melestarikan Plasma Nutfah. Bioedukasi, 6(1). 